\title{
Is post-traumatic growth possible in the parents of former patients of neonatal intensive care units?
}

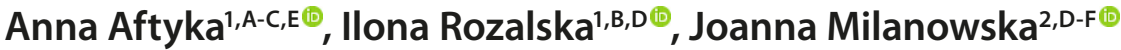 \\ ${ }^{1}$ Department of Anaesthesiological and Intensive Care Nursing, Medical University, Lublin, Poland \\ 2 Department of Applied Psychology, Medical University, Lublin, Poland \\ A - Research concept and design, B - Collection and/or assembly of data, C - Data analysis and interpretation, \\ $D$ - Writing the article, E-Critical revision of the article, F- Final approval of article
}

Aftyka A, Rozalska I, Milanowska J. Is post-traumatic growth possible in the parents of former patients of neonatal intensive care units? Ann Agric Environ Med. 2020; 27(1): 106-112. doi: 10.26444/aaem/105800

\begin{abstract}
Introduction. The birth of a sick child, as well as the infant's subsequent hospitalization in an neonatal intensive care unit (NICU), is undoubtedly stressful for the parents of the infant. Most studies conducted in groups of parents of such children focus on the assessment of the negative changes in their functioning due to such stress. The authors were interested in positive changes in the psychological functioning of parents that may occur after traumatic experiences. These changes are referred to as post-traumatic growth (PTG).

Objective. The aim of this study was to examine whether parents experience post-traumatic growth and to determine the predictors of PTG in fathers and mothers, depending on the coping strategy adopted.

Materials and method. The study involved 82 parents, whose children were previously hospitalized in neonatal intensive care unit. The methods used included the following standardized psychological tests: the Post-traumatic Growth Inventory, the Impact of Event Scale-Revised, and the COPE Inventory. Socio-demographic and medical data were also collected.

Results. Analysis of the data proved that the illness and hospitalization of a child are significantly associated with the occurrence of post-traumatic growth in parents. PTG in mothers is higher than in fathers. Predictors of PTG in fathers include the use of strategies aimed at seeking emotional support and positive reinterpretation and growth, while in the group of mothers, seeking emotional support, religious coping and planning were the coping strategies used.

Conclusions. Research on post-traumatic growth should be expanded. Knowledge of the predictors of positive growth in a difficult situation can contribute to the widespread implementation of primary and secondary prevention of post-traumatic stress symptoms as well as increase positive changes in individuals who have experienced traumatic events.
\end{abstract}

\section{Key words}

parents, PTSD, post-traumatic growth, PTG

\section{INTRODUCTION}

Childbirth is a stressful event, regardless of the length of time it takes. Research shows that it can cause a number of negative psychological reactions [1]. Despite significant advances in medicine in the last twenty years which have made it possible to rescue extremely immature children, prematurity continues to be one of the main causes of death, disease and disability $[2,3]$. Both the birth of a sick child and subsequent hospitalization in the neonatal intensive care unit (NICU) is stressful for both the mother and the child's father. Some describe this situation as 'trauma' The parents of these children are in a very difficult position, worried about the health and life of their offspring, the appearance and behaviour of the child, the large number of medical staff, the presence of other patients and the noise and alarms generated by the life support equipment $[4,5,6,7]$. During the child's hospitalization, the parents also experience a number of difficult emotions, such as fear, anxiety, guilt, helplessness and sadness. In addition, research indicates the occurrence of cognitive impairment among parents, such as a decrease

Address for correspondence: Joanna Milanowska, Department of Applied Psychology, Medical University of Lublin, Poland

E-mail:jmilanowska@yahoo.com

Received: 12.09.2019; accepted: 18.03.2019; first published: 18.04.2019 in the concentration of attention as well as problems with sleep and depression $[8,9,10]$.

Parents' experience of such intense stress may lead to a decrease in mental functioning, which may be manifested in the form of post-traumatic stress disorder (PTSD) or acute stress disorder (ASD). Most studies conducted in groups of parents of former patients of NICU focus on assessment of the occurrence of negative changes in their functioning [11]. However, is it possible to experience positive changes after such a traumatic experience? In recent years, researchers and practitioners have paid attention to this possibility. Positive changes are referred to as post-traumatic growth (PTG), which is defined as the occurrence of positive changes as a result of experienced trauma or unhappiness $[11,12,13$, $14,15]$.

The term post-traumatic growth was first used by Tedeschi and Calhoun in 1996 to describe a state in which traumas lead to positive changes in interpersonal relationships, selfperception and life philosophy. As a result of PTG, people are able to establish closer relationships with others, feel more empathy and compassion, and look at their past experiences from a distance. There may be changes in one's system of values, such as minor pleasures, meetings with friends, and in life awareness, may be perceived as more important. As a result of the trauma, a person begins to function at a higher 
level $[13,15]$. Studies conducted within the realm of PTG concern individuals who have survived natural disasters [16], sexual assault, and serious diseases, e.g., breast cancer $[17,18,19,20]$, as well as adults after treatment for neoplastic diseases in childhood [21] and in their families [22]. Some researchers have noted the occurrence of positive changes in people after the loss of relatives, such as a child [17], among healthy adults [23] and among firefighters [24].

In the last decade, researchers have tried to determine the predictors of PTG while taking into account sociodemographic variables, as well as different personality traits or coping strategies in difficult situations [15, 25]. Attention has also been drawn to the relationship between the occurrence of PTSD and PTG $[11,12,13,14]$. In Poland, research on positive changes related to the survival of a traumatic situation is rare.

\section{OBJECTIVE}

The aim of this study was to examine whether the parents of children previously hospitalized in NICU have PTG, and the occurrence of differences between fathers and mothers, as well as to determine the predictors of PTG in fathers and mothers, depending on the coping strategy adopted.

\section{MATERIALS AND METHOD}

The study involved 82 parents (41 mothers and 41 fathers) of children aged 3-12 months who were hospitalized in the NICU at the University Children's Hospital in Lublin, eastern Poland, from 1 July 201231 December 2014. Potential participants received information about the purpose of the study by telephone. After consent was obtained from participants, two copies of the questionnaires were sent to them (one copy for the mother, one copy for the father). The respondents also gave written consent to participate in the survey, and were issued with instructions on how to complete the forms, as well as a return envelope with an affixed stamp (in order not to incur any costs). The parents completed the questionnaires at home and returned them by post. Of the 160 people who agreed to participate in the study, 82 returned questionnaires which were completed correctly and in full.

The study used the following standardized tools:

Post-traumatic Growth Inventory (PTGI) - consists of 21 positively formulated statements describing various changes that have occurred as a result of an experienced traumatic event [26]. In the Polish version, the inventory examines changes occurring in four dimensions: (1) changes in selfperception; (2) relating to others; (3) appreciation of life; and (4) spiritual change [14].

Impact Event Scale-Revised (IES-R) - used to assess disorders occurring after traumatic stress. The scale is composed of 22 statements evaluated on a 5-point Likert scale; the overall scale includes three subscales: intrusion, arousal and avoidance [14].

COPE Inventory - a self-report tool composed of 60 statements that are answered on a 4-point scale. It is used to assess 15 strategies for responding to stressful situations.
Five scales measure different aspects of problem-focused coping (planning, positive reinterpretation and growth, active coping, suppression of competing activities, restraint), four other scales measure aspects of emotion-focused coping (focus on and venting of emotions, use of instrumental social support, use of emotional social support, religious coping), and six scales measure avoidance coping (denial, behavioural disengagement, humour, mental disengagement, substance use, and acceptance) [27].

The socio-demographic and medical data of the parents and infants (including gestational age of the child during labour, body weight, diseases of basic systems, past surgeries and period of hospitalization) were also collected.

The research project was approved by the Bioethics Committee at the Medical University in Lublin (KE0254/77/2013).

\section{RESULTS}

The research sample was chosen in a targeted manner, and consisted of two parallel groups: 41 fathers and 41 mothers of infants aged $3-11$ months $(M=7.07 \pm 2.47)$, hospitalized in the past in the NICU. The largest group were people between the ages of $25-9-85.4 \%$ of fathers $(\mathrm{N}=35)$ and $85.4 \%$ of mothers $(\mathrm{N}=35)$. The highest percentage of couples surveyed were parents who had ed one $(\mathrm{N}=16,39.0 \%)$ or two children $(\mathrm{N}=16,39.0 \%)$. The highest number of respondents had secondary education: 25 fathers $(61 \%)$ and 22 mothers (53.7\%).

The average gestational age of new-borns was 34.5 weeks $(\mathrm{M}=34.54 \pm 5.10)$, with the shortest pregnancy lasting 23 weeks and the longest lasting 41 weeks. The average child score on the Apgar scale was slightly above six points $(M=6.02 \pm 3.15)$, and the average birth weight of newborns was less than 2,400 grams $(M=2375 \pm 991)$. The average time of hospitalization of the children was more than 20 days $(M=20.29 \pm 24.36)$. Of the hospitalized newborns, $92.7 \%$ of them survived $(\mathrm{N}=38)$. Patients were diagnosed with diseases of the respiratory system $(\mathrm{N}=35,85.4 \%)$, cardiovascular system $(\mathrm{N}=16,39.0 \%)$ and nervous system $(\mathrm{N}=13,31.7 \%)$. One-third of the children underwent various types of operations $(\mathrm{N}=14,34.1 \%)$, and two-thirds had infections ( $\mathrm{N}=27,65.9 \%)$ (Tab. 1).

The average post-traumatic growth level in the group of mothers was $3.05 \pm 0.88$, and $t$ in the group of fathers $-2.89 \pm 1.32$. Analysis of the obtained data showed that the majority of respondents indicated the illness and hospitalization of the child as an initiation experience for PTG $-78.0 \%$ of fathers $(\mathrm{N}=32)$ and $75.6 \%$ of mothers $(\mathrm{N}=31)$ (Tab. 2).

The next step was to indicate statistically significant differences in both groups of respondents stating different reasons for experiencing post-traumatic growth due to the general outcome of PTG and its individual dimensions: changes in self-perception, changes in relationships with others, greater appreciation of life and spiritual changes. Analysis of the obtained results indicated no statistically significant differences in the group of fathers, while in the group of mothers, the differences referred only to women who connected their growth with the health situation of the childs $(M=3.14 \pm 0.98)$. They were also characterized by greater changes in relationships with others than the mothers who did not see the reasons for their post-traumatic 
Table 1. Characteristics of the research groups

\begin{tabular}{|c|c|c|c|c|c|}
\hline \multirow{3}{*}{ Variables } & & \multicolumn{4}{|c|}{ Studygroup } \\
\hline & & \multicolumn{2}{|c|}{$\begin{array}{l}\text { Group of fathers } \\
\qquad N=41\end{array}$} & \multicolumn{2}{|c|}{$\begin{array}{c}\text { Group of mothers } \\
\qquad N=41\end{array}$} \\
\hline & & N & $\%$ & N & $\%$ \\
\hline \multirow{3}{*}{ Parents'age } & $18-24 y$. & 1 & 2.4 & 6 & 14.6 \\
\hline & $25-39 y$. & 35 & 85.4 & 35 & 85.4 \\
\hline & $40-59 y$. & 5 & 12.2 & 0 & 0.0 \\
\hline \multirow{3}{*}{$\begin{array}{l}\text { Parents' } \\
\text { education }\end{array}$} & Elementary & 4 & 9.8 & 3 & 7.3 \\
\hline & Secondary & 25 & 61.0 & 22 & 53.7 \\
\hline & Higher & 12 & 29.3 & 16 & 39.0 \\
\hline \multirow{6}{*}{$\begin{array}{l}\text { Number of } \\
\text { children }\end{array}$} & & \multicolumn{2}{|c|}{ N } & \multicolumn{2}{|c|}{$\%$} \\
\hline & One & \multicolumn{2}{|c|}{16} & \multicolumn{2}{|c|}{39.0} \\
\hline & Two & \multicolumn{2}{|c|}{16} & \multicolumn{2}{|c|}{39.0} \\
\hline & Three & \multicolumn{2}{|c|}{7} & \multicolumn{2}{|c|}{17.1} \\
\hline & Four & \multicolumn{2}{|c|}{2} & \multicolumn{2}{|c|}{4.9} \\
\hline & & M & SD & Min. & Max. \\
\hline \multicolumn{2}{|c|}{ Child's gestational age } & 34.54 & 5.10 & 23 & 41 \\
\hline \multicolumn{2}{|c|}{ Scoring on the Apgar scale } & 6.02 & 3.15 & 1 & 10 \\
\hline \multicolumn{2}{|l|}{ Birth weight } & 2375.91 & 991.47 & 750.00 & 3980.00 \\
\hline \multicolumn{2}{|l|}{ Child's age } & 7.07 & 2.47 & 3 & 11 \\
\hline \multicolumn{2}{|c|}{ Time of hospitalization } & 20.29 & 24.36 & 3 & 130 \\
\hline & & \multicolumn{2}{|c|}{$N$} & \multicolumn{2}{|c|}{$\%$} \\
\hline \multicolumn{2}{|l|}{ Child survival } & \multicolumn{2}{|c|}{38} & \multicolumn{2}{|c|}{92.7} \\
\hline \multicolumn{2}{|c|}{ Respiratory disease } & \multicolumn{2}{|c|}{35} & \multicolumn{2}{|c|}{85.4} \\
\hline \multicolumn{2}{|c|}{ Cardiovascular disease } & \multicolumn{2}{|c|}{16} & \multicolumn{2}{|c|}{39.0} \\
\hline Nervous syste & sease & 13 & & & \\
\hline Surgeries & & 1 & & & \\
\hline Infections & & 2 & & & \\
\hline
\end{tabular}

Table 2. Categories of the causes of posttraumatic growth

\begin{tabular}{lcccc}
\hline \multirow{2}{*}{ Category of reason } & \multicolumn{3}{c}{ Group of fathers } & \multicolumn{2}{c}{ Group of mothers } \\
\cline { 2 - 5 } & $\mathrm{N}$ & $\%$ & $\mathrm{~N}$ & $\%$ \\
\hline Causes related to the child & 32 & 78.0 & 31 & 75.6 \\
\hline Causes not related to the child & 9 & 22.0 & 9 & 22.0 \\
\hline No data & 0 & 0.0 & 1 & 2.4 \\
\hline Altogether & 41 & 100.0 & 41 & 100.0 \\
\hline
\end{tabular}

Table 3. Differences between mothers with different reasons for posttraumatic growth

\begin{tabular}{|c|c|c|c|c|c|c|}
\hline Variables & Causes of PTG & $N$ & $M$ & $S D$ & $U$ & $p$ \\
\hline \multirow{2}{*}{$\begin{array}{l}\text { Changes } \\
\text { in self- } \\
\text { perception }\end{array}$} & Connected with the child & 31 & 3.71 & 1.30 & \multirow{2}{*}{120.500} & \multirow{2}{*}{0.522} \\
\hline & Not connected with the child & 9 & 3.33 & 1.66 & & \\
\hline \multirow{2}{*}{$\begin{array}{l}\text { Relating to } \\
\text { others }\end{array}$} & Connected with the child & 31 & 3.14 & 0.98 & \multirow{2}{*}{76.000} & \multirow{2}{*}{0.039} \\
\hline & Not connected with the child & 9 & 2.24 & 1.23 & & \\
\hline \multirow{2}{*}{$\begin{array}{l}\text { Appreciation } \\
\text { of life }\end{array}$} & Connected with the child & 31 & 3.63 & 0.93 & \multirow{2}{*}{95.500} & \multirow{2}{*}{0.153} \\
\hline & Not connected with the child & 9 & 3.06 & 1.34 & & \\
\hline \multirow{2}{*}{$\begin{array}{l}\text { Spiritual } \\
\text { changes }\end{array}$} & Connected with the child & 31 & 4.11 & 0.83 & \multirow{2}{*}{93.500} & \multirow{2}{*}{0.132} \\
\hline & Not connected with the child & 9 & 3.26 & 1.44 & & \\
\hline \multirow{2}{*}{$\begin{array}{l}\text { Posttraumatic } \\
\text { growth }\end{array}$} & Connected with the child & 31 & 3.05 & 1.29 & \multirow{2}{*}{105.000} & \multirow{2}{*}{0.259} \\
\hline & Not connected with the child & 9 & 2.56 & 1.33 & & \\
\hline
\end{tabular}

growth in circumstances related to premature birth and child hospitalization $(\mathrm{M}=2.24 \pm 1.28, \mathrm{U}=76.000 ; \mathrm{p}<0.05)$ (Tab. 3$)$.

Further analyses concerned the differences between the fathers' group and the mothers' group in terms of severity of the post-traumatic growth. The obtained data suggested stronger changes in the perception of self in the group of mothers $(\mathrm{M}=3.56 \pm 1.42)$ than in the group of fathers $(\mathrm{M}=2.85 \pm 0.88 ; \mathrm{Z}=2.763 ; \mathrm{p}<0.01)$. In mothers, there was also a higher intensity of spiritual changes $(M=3.85 \pm 1.13)$ than in fathers $(\mathrm{M}=2.43 \pm 1.23 ; \mathrm{Z}=4.342 ; \mathrm{p}<0.001)$ (Tab. 4).

The next step was to indicate whether the post-traumatic growth co-occurs with the intensity of post-traumatic stress symptoms and strategies for coping with stress, in the groups of both fathers and mothers. The obtained correlation coefficients in the group of fathers indicated that there was an average directly proportional relationship between the severity of post-traumatic growth and the search for emotional support $(\mathrm{r}=0.36 ; \mathrm{p}<0.05)$ and the positive average relationship between the analysed dimension and positive reinterpretation and growth $(\mathrm{r}=0.34 ; \mathrm{p}<0.05)$ (Tab. 5).

Table 4. Differences between fathers and mothers in the scope of the intensification of posttraumatic growth

\begin{tabular}{|c|c|c|c|c|c|}
\hline Variables & $N$ & $M$ & $S D$ & $Z$ & $p$ \\
\hline Changes in self-perception - fathers & 41 & 2.85 & 0.88 & \multirow{2}{*}{2.763} & \multirow{2}{*}{0.006} \\
\hline Changes in self-perception - mothers & 41 & 3.56 & 1.42 & & \\
\hline Relating to others- fathers & 41 & 3.27 & 0.96 & \multirow{2}{*}{1.516} & \multirow{2}{*}{0.129} \\
\hline Relating to others- mothers & 41 & 2.89 & 1.12 & & \\
\hline Appreciation of life - fathers & 41 & 3.56 & 1.05 & \multirow{2}{*}{0.395} & \multirow{2}{*}{0.693} \\
\hline Appreciation of life - mothers & 41 & 3.44 & 1.08 & & \\
\hline Spiritual changes - fathers & 41 & 2.43 & 1.23 & \multirow{2}{*}{4.342} & \multirow{2}{*}{0.001} \\
\hline Spiritual changes - mothers & 41 & 3.85 & 1.13 & & \\
\hline Posttraumatic growth - fathers & 41 & 3.05 & 0.88 & \multirow{2}{*}{0.505} & \multirow{2}{*}{0.613} \\
\hline Posttraumatic growth - mothers & 41 & 2.89 & 1.32 & & \\
\hline
\end{tabular}

Table 5. Values of correlation coefficients between the intensity of posttraumatic growth and PTSS and strategies for coping with stress in the fathers group

\begin{tabular}{lc}
\hline Variables & Posttraumatic growth \\
\hline PTSS & -0.01 \\
\hline Active coping & -0.02 \\
\hline Planning & 0.03 \\
\hline Use of instrumental social support & 0.29 \\
\hline Use of emotional social support & $0.36^{*}$ \\
\hline Suppression of competing activities & -0.09 \\
\hline Religious coping & 0.01 \\
\hline Positive reinterpretation and growth & $0.34^{*}$ \\
\hline Behavioural disengagement & -0.03 \\
\hline Acceptance & 0.15 \\
\hline Focus on and venting of emotions & -0.06 \\
\hline Denial & -0.12 \\
\hline Mental disengagement & -0.06 \\
\hline Restraint & 0.04 \\
\hline Substance use & -0.24 \\
\hline Humour & 0.15 \\
\hline * p $<0.05$ &
\end{tabular}


In the group of mothers, the conducted analyses showed that there was a strong directly proportional relationship between the severity of post-traumatic growth and the use of instrumental social support $(\mathrm{r}=0.51 ; \mathrm{p}>0.01)$. In addition, there was an average positive correlation between the intensity of PTG and active coping $(r=0.50 ; \mathrm{p}>0.01)$, planning $(\mathrm{r}=0.44$; $\mathrm{p}>0.01)$, use of emotional social support $(\mathrm{r}=0.49 ; \mathrm{p}>0.01)$, suppression of competing activities $(\mathrm{r}=0.41 ; \mathrm{p}>0.01)$, positive reinterpretation and growth $(\mathrm{r}=0.35 ; \mathrm{p}>0.05)$, and focus on and venting of emotions $(r=0.39 ; \mathrm{p}>0.05)$ (Tab.6).

Table 6. Values of correlation coefficients between the intensity of posttraumatic growthand PTSS and strategies for coping with stress in a group of mothers

\begin{tabular}{lc}
\hline Variables & Posttraumatic growth \\
\hline PTSS & 0.26 \\
\hline Active coping & $0.50^{* *}$ \\
\hline Planning & $0.44^{* *}$ \\
\hline Use of instrumental social support & $0.51^{* *}$ \\
\hline Use of emotional social support & $0.49^{* *}$ \\
\hline Suppression of competingactivities & $0.41^{* *}$ \\
\hline Religious coping & 0.21 \\
\hline Positive reinterpretation and growth & $0.35^{*}$ \\
\hline Behavioural disengagement & 0.12 \\
\hline Acceptance & 0.05 \\
\hline Focus on and venting of emotions & $0.39^{*}$ \\
\hline Denial & -0.23 \\
\hline Mental disengagement & -0.02 \\
\hline Restraint & -0.09 \\
\hline Substanceuse & -0.06 \\
\hline Humour & 0.12 \\
\hline * p<0.05; ${ }^{* *}<0.01$ &
\end{tabular}

The last stage of the research was to show the predictors of post-traumatic growth in both groups. The first step in the group of fathers was the introduction of the use of emotional social support into the variable model. The model proved to be correctly matched to the data and explained $11.0 \%$ (adjusted $\mathrm{R}^{2}=0.11$ ) of the variance in the severity of posttraumatic growth $(\mathrm{F}(1,39)=5.892, \mathrm{p}<0.05)$. To increase the percentage range of explained variance, in the second step, a positive reinterpretation and growth was introduced into the model as an additional explanatory variable. The proposed model is well suited to the data and explains $20.0 \%$ (adjusted $\left.\mathrm{R}^{2}=0.20\right)$ of the variance in the severity of PTG $(\mathrm{F}$ $(2,38=6.006 ; \mathrm{p}<0.005)$.

The analyses performed indicate that in the group of men, significant predictors of post-traumatic growth are the use of strategies in stressful situations aimed at emotional social support $(\beta=0.386 ; p<0.05)$ and positive reinterpretation and growth $(\beta=0.330 ; p<0.05)$. The subsequent steps of the conducted hierarchical regression analysis in the group of fathers are presented in Table 7.

In the group of mothers, the first step was to introduce into the model a coping strategy known as a turn towards religion. The model proved to be well-suited to the data and explained $33.0 \%$ (adjusted $\mathrm{R}^{2}=0.33$ ) of the variance in the dependent variable $(F(1,39)=20.817$; $p<0.001)$. To obtain a more precise explanation of the conditions of post-
Table 7. Model of hierarchical regression analysis in the fathers group. Variable explained: intensification of posttraumatic growth. Explanatory variables: Use of emotional social support,positive reinterpretation and growth

\begin{tabular}{|c|c|c|c|c|c|c|c|c|}
\hline \multirow{2}{*}{ Model } & \multicolumn{3}{|c|}{ Model matchingmeasures } & \multicolumn{5}{|c|}{ Regressionweights and predictors } \\
\hline & $R^{2}$ adjusted & $F$ & $p$ & $B$ & $S$ & Beta & $t$ & $p$ \\
\hline \multicolumn{9}{|c|}{ Step 1} \\
\hline (Constant) & & & & 44.993 & 8.442 & & 5.330 & 0.001 \\
\hline $\begin{array}{l}\text { Use of } \\
\text { emotional } \\
\text { social } \\
\text { support }\end{array}$ & 0.109 & 5.892 & 0.020 & 8.105 & 3.339 & 0.362 & 2.427 & 0.020 \\
\hline \multicolumn{9}{|c|}{ Step 2} \\
\hline (Constant) & \multirow{3}{*}{0.200} & \multirow{3}{*}{6.006} & \multirow{3}{*}{0.005} & 19.872 & 13.409 & & 1.482 & 0.147 \\
\hline $\begin{array}{l}\text { Use of } \\
\text { emotional } \\
\text { social } \\
\text { support }\end{array}$ & & & & 7.937 & 3.164 & 0.355 & 2.508 & 0.017 \\
\hline $\begin{array}{l}\text { Positive } \\
\text { reinter- } \\
\text { pretation } \\
\text { and growth }\end{array}$ & & & & 10.086 & 4.321 & 0.330 & 2.334 & 0.025 \\
\hline
\end{tabular}

traumatic growth, a variable for planning, which is another type of coping strategy in problem situations, was introduced into the model in the second step. The model also proved to be correctly matched to the data and explained $41.0 \%$ (adjusted $\mathrm{R}^{2}=0.41$ ) of the variance in the explained variable, F $(2,38)=14.768, \mathrm{p}<0.001$. The developed model revealed two strategies to be significant predictors of post-traumatic growth in the group of mothers: religious coping ( $\beta=0.585$; $\mathrm{p}<0.001)$ and planning $(\beta=0.299 ; \mathrm{p}<0.05)($ Tab.8).

Table 8. Model of hierarchical regression analysis in the group of mothers. Explained variable: intensification of posttraumatic growth. Explanatory variables: religious coping, planning

\begin{tabular}{|c|c|c|c|c|c|c|c|c|}
\hline \multirow{2}{*}{ Model } & \multicolumn{3}{|c|}{ Model matching measures } & \multicolumn{5}{|c|}{ Regression weights and predictors } \\
\hline & $R^{2}$ adjusted & $F$ & $p$ & B & $S$ & Beta & $t$ & $p$ \\
\hline \multicolumn{9}{|c|}{ Step 1} \\
\hline (Constant) & \multirow[b]{2}{*}{0.331} & \multirow[b]{2}{*}{20.817} & \multirow[b]{2}{*}{0.001} & 0.690 & 0.511 & & 1.350 & 0.185 \\
\hline $\begin{array}{l}\text { Religious } \\
\text { coping }\end{array}$ & & & & 0.773 & 0.169 & 0.590 & 4.563 & 0.001 \\
\hline \multicolumn{9}{|c|}{ Step 2} \\
\hline (Constant) & \multirow{3}{*}{0.408} & \multirow{3}{*}{14.768} & \multirow{3}{*}{0.001} & -1.194 & 0.905 & & -1.319 & 0.195 \\
\hline $\begin{array}{l}\text { Religious } \\
\text { coping }\end{array}$ & & & & 0.767 & 0.159 & 0.585 & 4.810 & 0.001 \\
\hline Planning & & & & 0.697 & 0.284 & 0.299 & 2.456 & 0.019 \\
\hline
\end{tabular}

\section{DISCUSSION}

The occurrence of negative changes in the mental functioning of people who have survived a traumatic event is well documented. Researchers have noted the aspect of positive change, and because of this research, the number of empirical studies on post-traumatic growth is increasing [26, 28, 29].

Most studies on PTG have been conducted in patients treated for cancer. The results of an Asian study indicate the occurrence of moderate PTG levels in patients treated for cancer and in their family members, with higher results for the patients [30]. Studies carried out by Yi et al. in a group of 
young adults aged $18-39$ who were treated in childhood due to neoplastic disease, showed that $88.5 \%$ experienced moderate post-traumatic growth. The highest results were obtained by the respondents in the domain of greater appreciation of life [31]. In turn, Tanriverd et al. showed a high level of PTG among patients treated for cancer, and the largest changes occurred in the range of changes in self-perception [32]. Similar results were obtained by Mehrabi et al. in a group of women suffering from breast cancer. All respondents showed changes in the domain of greater appreciation of life [33].

Studies also show that parents grieving after the loss of a child also experience post-traumatic growth [23, 34]. The occurrence of positive growth has also been presented in studies by Büchi et al., in which they indicated that up to $80 \%$ of those who mourn after losing relatives are able to see the positive side of this difficult situation [35]. The results of studies carried out in a group of high-risk pregnancies, showed that parents experience post-traumatic growth at a moderate to high level, and the largest changes occur in the domain of changes in self-perception [36]. A study by Sawyer et al. conducted in a group of women after childbirth indicated that they experience post-traumatic growth (47.9\% at a low level); the largest changes are observed in the domain of greater appreciation of life, which was reported by $68.1 \%$ of mothers [37].

The current findings are consistent with the subject of positive changes experienced by people who have survived a potentially traumatizing event, which includes the premature birth of a child and related health problems, as well as the hospitalization of newborns. A similar study was carried out by Jenewein et al. in 2008, who assessed the mental functioning of parents of extreme pre-term infants. In their studies, they compared the condition of people who were in mourning to parents whose children had survived. They showed that individuals in bereavement are characterized by a higher level of PTG, compared to those whose children survived, especially in terms of relationships with others. They also proved that mothers in bereavement achieved higher post-traumatic growth than the fathers [38]. The results of the current research indicate that both fathers and mothers of children hospitalized in NICU feel moderate posttraumatic growth. The majority of respondents $(78.0 \%$ of fathers and $75.6 \%$ of mothers) perceived that it is related to the prematurity, illness and hospitalization of the child. In terms of the individual dimensions of PTG (changes in self-perception, changes in relationships with others, greater appreciation of life and spiritual changes), fathers diud not differ from one another. In contrast, mothers who related their post-traumatic growth to the child's health situation were characterized by greater changes in relationships with people. Changes in their relationships with other people were expressed primarily with increased compassion and sensitivity to others, and a greater willingness to open up to others [14].

Comparison of data in both groups indicate that women to a greater extent notice the change in their self-perception. Changes in self-perception are related primarily to the feeling of being a better person, an increase in personal strength, and a higher sense of self-worth and effectiveness, because such people have more confidence in themselves and their own capabilities, as well as with respect to future events [14]. Mothers are also more strongly affected than fathers by the intensity of spiritual changes. This finding is probably related to the fact that women, more often than men, choose to turn to religion as a method of coping with a difficult situation over which they have no control.

With the increase in the number of post-traumatic growth publications, there has developed research on the factors that predict its occurrence. The results of research conducted among women suffering from breast cancer indicate that PTG occurs in a short period of time from the diagnosis of the disease, and increases over time, while one of the predictors of post-traumatic growth is active coping [39]. Similar results are shown by Kolokotroni et al., who analysed the literature on women treated for breast cancer. They showed that posttraumatic growth is associated with the following strategies for coping with stress: religious coping, active coping, positive reinterpretation and growth, and acceptance [20]. A literature analysis by Prati and Pietrantoni showed that post-traumatic growth is associated with strategies for coping with stress that encompass acceptance, seeking support, positive reinterpretation and growth and religious coping [40].

The presented research shows that in the group of fathers, a significant predictor of post-traumatic growth in stressful situations is the use of strategies aimed at seeking emotional support and positive reinterpretation and growth. On the other hand, in the group of women, important predicators included religious coping and planning. These results show how important and underestimated emotional support and psychological care are for men after traumatic experiences. Men are less likely than women to receive this help, but they need it just as much, if not more, than women. This fact is confirmed by numerous studies indicating the relationship between the lack of social support in men and their susceptibility to depressive disorders [41].

The pattern of attitudes towards relations is absorbed and implemented by women [42]. Interpersonal relations have been listed as a life priority by participants of nationwide, representative surveys and qualitative in-depth interviews conducted by Frąckowiak [42]. The current study, however, indicates that for women, in addition to emotional support from other people, more important coping strategies for traumatic situations include a return to religious values, and the ability to plan actions in a difficult emotional situation. The importance of religious coping in the process of positive post-traumatic changes has also been indicated by other researchers $[34,43,44,45,46]$. The role of this method of coping seems to be particularly important in situations beyond the control of the person going through a difficult experience, such as the course of an illness in a premature child. Appealing to religion makes it possible to search for meaning and to give meaning to an experienced situation [34].

Reports from 2013 show that there is a relationship between the occurrence of post-traumatic growth and lower education [47]. The current study does not confirm this finding. The interdependence in this aspect may not have been demonstrated because the test group was too homogeneous.

Studies show that there is a relationship between the occurrence of PTSD and post-traumatic growth [48]. The literature review indicated the presence of both a negative and positive relationship. Literature analysis shows that this relationship is well documented, especially among patients suffering from breast cancer [47]. The presented analysis of the research material indicates that the intensity of the trauma experienced was not related to the severity of post- 
traumatic growth in the parents of children who had been hospitalized in the NICU in the past.

\section{CONCLUSIONS AND CLINICAL IMPLICATIONS}

The illness and hospitalization of a child are significantly associated with the occurrence of PTG in the parents. PTG is higher in mothers than in fathers. Mothers are more strongly affected by changes in their perception of themselves and spiritual changes than are the fathers. Predicators of PTG in fathers are the use of strategies aimed at seeking emotional support and positive re-evaluation. Although men rarely admit it explicitly, emotional social support is surprisingly a very important determinant of their post-traumatic growth among men.

The predictors of post-traumatic growth in the group of mothers are seeking emotional support, religious coping and planning. Women, in addition to emotional support from others, need a sense of control over a difficult situation, and when they lose it, the most effective method of dealing with trauma is intensifying their spiritual life.

Identified predictors of post-traumatic growth indicate that individuals exposed to a traumatic event associated with the illness and hospitalization of a child should be provided to a greater extent with psychological and psychotherapeutic help, which would provide them with both emotional support and the possibility of a positive reinterpretation of difficult events. This suggestion applies, above all, to men who, less often, express the need for such assistance, although its provision results in positive changes in the emotional, cognitive and behavioural reactions related to the traumatic situation. Because the predictors of post-traumatic growth in the group of mothers is the use of planning strategies, it could be beneficial for women experiencing the illness and hospitalization of a child to be actively involved in planning the treatment and care of the sick child. Cooperation and mutual communication between the doctor and the parents of the child is therefore very important. Analysis of the results obtained in this study also indicate the importance of providing parents of sick children, especially their mothers, access to spiritual care, as the strategy of religious coping in difficult situations was a predictor of post-traumatic growth.

Research on post-traumatic growth should be expanded to properly and effectively identify the factors that affect it. Knowledge of the predictors of positive changes in a difficult situation can contribute to the widespread implementation of primary and secondary prevention of emotional-cognitive disorders in the trauma experience, as well as increase positive changes in individuals who have experienced trauma.

\section{REFERENCES}

1. Ayers S, Pickering AD. Do Women Get Post-traumatic Stress Disorder as a Result of Childbirth. A Prospective Study of Incidence. Birth. 2001; 28 (2): 111-118.

2. Rutkowska M. Noworodek urodzony na granicy możliwości przeżycia. Medycyna Wieku Rozwojowego. 2011; XV(3): 356-367 (in Polish).

3. Lasiuk GC, Comeau T, Newburn-Cook Ch. Unexpected: an interpretive description of parental traumas' associated with preterm birth. BMC Pregnancy and Childbirth 13. 2013; (suppl 1): 13-23.

4. Łuczak-Wawrzyniak J, Czarnecka M, Konofalska N, Bukowska A, Gadzinowski J. Holistyczna koncepcja opieki nad wcześniakiem lub/i dzieckiem chorym - pacjentem Oddziału. Perinatologia, Neonatologia i Ginekolgia. 2010; 3 (1): 63-67 (in Polish).
5. Gruszczyńska M, Sierpień-Wójcik G, Bąk-Sosnowska M, Perlak M Jak wcześniactwo dzieci wpływa na psychiczne funkcjonowanie ich rodziców? Probl Med Rodz. 2014; 45-46 (1-2): 7-12 (in Polish).

6. Franck LS, Cox SA, Alison WI. Measuring neonatal intensive care unitrelated parental stress. J AdvNurs. 2005; 49 (6): 608-615. Available at: 10.1111/j.1365-2648.2004.03336.x.

7. Grosik C. Identification of Internal and External Stressors in Parents of Newborns in Intensive Care. PERMJ. 2013; 17 (3): 36-41. Available at: $10.7812 / \mathrm{TPP} / 12-105$.

8. Busse M, Stromgren K, Thorngate L, Thomas KA. Parents' Responses to Stress in the Neonatal Intensive Care Unit. Critical Care Nurse. 2013; 33(4): 52-59. Available at: $10.4037 / \mathrm{ccn} 2013715$.

9. Obeidat HM, Bond EA, Callister LC. The Parental Experience of Having an Infant in the Newborn Intensive Care Unit. J Perinat Educ. 2009; 18(3): 23-29. Doi: 10.1624/105812409X461199.

10. Baía I, Alves E, Amorim M, Fraga S, Silva S. Parental needs and stress in neonatal intensive care units: effect of data collection period. Arq Med. 2015; 29 (6)

11. Ayache R, Benticha S, Goutaudier N, Chabrol H. Psychiatric outcomes after childbirth. Can post-traumatic growth protect me from disordered eating symptoms? Arch Gynecol Obstet. 2015; Available at: 10.1007/ s00404-015-3969-6.

12. Bensimon M. Elaboration on the association between trauma, PTSD and post-traumatic growth. The role of trait resilience. Personality and Individual Differences. 2012; 52 (7): 782-787. Available at: 10.1016/j. paid.2012.01.011.

13. Ogińska-Bulik N. Postraumatyczny wzrost - zróżnicowanie ze względu na rodzaj doświadczonego zdarzenia oraz płeć i wiek badanych osób. Acta Universitatis Lodziensis Folia Psychologica. 2013; 17: 51-66 (in Polish).

14. Ogińska-Bulik N, Juczyński Z. Rozwój potraumatyczny charakterystyka i pomiar. Psychiatria. 2010; 7(4): 129-142 (in Polish).

15. Ogińska-Bulik N, Kobylarczyk M. Relation between resiliency and posttraumatic growth in a group of paramedics: the mediating role of coping strategies. Int J Occup Med Environ Health. 2015; 28 (4): 707-719.

16. Bianchini V, Roncone R, Giusti L, Casacchia M, Cifone MG, Pollice R. PTSD Growth and Substance Abuse Among a College Student Community: Coping Strategies after 2009 L'aquila Earthquake. Clin Pract Epidemiol Ment Health. 2015; 11: 140-143.

17. Barakat LP, Alderfer MA, Kazak AE. Post-traumatic growth in adolescent survivors of cancer and their mothers and fathers. J Pediatr Psychol. 2006; 31 (4): 413-419.

18. Danhauer SC, Case LD, Tedeschi R, Russell G, Vishnevsky T, Triplett Kelli et al. Predictors of post-traumatic growth in women with breast cancer. Psycho-Oncology. 2013; 22(12): 2676-2683.

19. Moore AM, Gamblin TC, Geller DA, Youssef MN, Hoffman KE, Gemmell L et al. A prospective study of post-traumatic growth as assessed by self-report and family caregiver in the context of advanced cancer. Psycho-Oncology. 2011; 20 (5).

20. Kolokotroni P, Anagnostopoulos F, Tsikkinis A. Psychosocial Factors Related to Post-traumatic Growth in Breast Cancer Survivors. A Review. Women Health. 2014; 54 (6): 569-592. Available at: 10.1080/03630242.2014.899543.

21. Gianinazzi ME, Rueegg CS, Vetsch J, Lüer S, Kuehmi CE, Michel G. Cancer's positive flip side: post-traumatic growth after childhood cancer. Support Care Cancer. 2016; 24(1): 195-203.

22. Picararo JA. Womer JW, Kazak AE, Feudtner C. Post-traumatic Growth in Parents and Pediatric Patients. J Palliat Med. 2014; 17 (2): 209-218.

23. Engelkemeyer SM, Marwit SJ. Post-traumatic growth in bereaved parents. J Traum Stress. 2008; 21 (3): 344-346. Available at: 10.1002/ jts. 20338 .

24. Sattler DN, Boyd B, Kirsch J. Trauma-exposed Firefighters. Relationships among Post-traumatic Growth, Post-traumatic Stress, Resource Availability, Coping and Critical Incident Stress Debriefing Experience. Stress Health. 2014; 30 (5): 356-365. DOI: 10.1002/smi.2608.

25. Karanci N, Işıklı S, Aker AT, Gül Eİ, Erkan B, O“zkol H, Gu“zel HY. Personality, post-traumatic stress and trauma type: factors contributing to post-traumatic growth and its domains in a Turkish community sample. Eur J Psychotraumatol. 2012; (3). Available at: 10.3402/ejpt. v3i0.17303.

26. Tedeschi RG, Calhoun LG. The post-traumatic growth inventory: Measuring the positive legacy of trauma. J Traumatic Stress. 1996; 9 (3): 455-471.

27. Juczyński Z, Ogińska-Bulik N. Wielowymiarowy Inwentarz do Pomiaru Radzenia Sobie ze Stresem, In: Narzędzia do Pomiaru Stresu i Radzenia Sobie ze Stresem. Pracownia Testów Psychologicznych. Warszawa 2009; 23-44 (in Polish). 
28. Zoellner T, Maercker A. Post-traumatic growth in clinical psychology - A critical review and introduction of a two component model Clin Psychol Rev. 2006; 26 (5): 626-653. Available at: 10.1016/j. cpr.2006.01.008.

29. Meyerson DA, Grant KE, Carter JS, Kilmer RP. Post-traumatic growth among children and adolescents. A systematic review. Clin Psychol Rev 2011; 31 (6): 949-964. Available at: 10.1016/j.cpr.2011.06.003.

30. Tahory Hale, Mohammadian R, Rahmani A, Seyedrasooli A, Lackdezajy S, Heigarzadeh M. Viewpoints of family caregivers about post-traumatic growth in cancer patients. Asian Pac J Cancer Prev. 2016; 17 (2): 755-758.

31. Yi J, Zebrack B, Kim MA, Cousino M. Post-traumatic Growth Outcomes and Their Correlates Among Young Adult Survivors of Childhood Cancer. J Pediatr Psychol. 2015; 40 (9): 981-991. Available at: 10.1093/ jpepsy/jsv075.

32. Tanriverd D, Savas E, Can G. Post-traumatic Growth and Social Support in Turkish Patients with Cancer. Asian Pacific Journal of Cancer Prevention. 2012; 13 (9): 4311-4314. Available at: 10.7314/ APJCP.2012.13.9.4311

33. Mehrabi E, Hajian S, Simbar M, Houshyari M, Zayeri F. Post-traumatic growth: a qualitative analysis of experiences regarding postive psychological changes among Iranian women with breast cancer. Electrinic Physician. 2015; 7 (5): 1239-1246.

34. Ogińska-Bulik N. Radzenie sobie ze stratą dziecka a występowanie pozytywnych zmian potraumatycznych. Psychologia Kliniczna Zdrowia. 2017; 23 (1): 159-166. Availableat: 10.14691/CPPJ.23.1.159 (in Polish).

35. Büchi S, Bucher HU, Sensky T. Grief and post-traumatic growth in parents 2-6 years after the death of their extremely premature baby. Psychoterap Psychosom. 2007; 76: 106-114. Available at: 10.1159/000097969.

36. Ha JY, Sim BY. Post-traumatic growth after high risk pregnancy. Ady Sci Technol Latters. 2015; 88: 272-275.

37. Sawyer A, Ayers S, Young D, Bradley R, Smith H. Post-traumatic growth after childbirth. A prospective study. Psychology Health. 2012; 27 (3): 362-377. Availableat: 10.1080/08870446.2011.578745
38. Jenewein, J, Moergeli H, Fauchère JC, Bucher HU, Kraemer B, Wittmann L et al. Parents' mental health after the birth of an extremely preterm child: A comparison between bereaved and non-bereaved parents. J Psychomatic Obstet Gynecol. 2008; 29(1): 53-60.

39. Danhauer SC, Case LD, Tedeschi R, Russell G, Vishnevsky T, Triplett, $\mathrm{K}$ et al. Predictors of post-traumatic growth in women with breast cancer. Psycho-Oncology. 2013; 22(12): 2676-2683. Available at: 10.1002/pon.3298.

40. Prati G, Pietrantoni L. Optimism, Social Support, and Coping Strategies As Factors Contributing to Post-traumatic Growth. A Meta-Analysis. J Loss Trauma. 2009; 14(5): 364-388. Available at: $10.1080 / 15325020902724271$

41. Hart AD. Męska depresja. Wydawnictwo W drodze. Poznań 2006 (in Polish).

42. Frąckowiak-Sochańska M. Zdrowie psychiczne kobiet i mężczyzn. Płeć społeczno-kulturowa a kategorie „zdrowia psychicznego” i „chorób psychicznych”. Nowiny lekarskie 2011; 80(5): 394-406 (in Polish).

43. Helgeson VS, Reynolds KA, Tomich PL. A meta-analytic review of benefit Winding and groth. J Consult Clin Psychol. 2006; 74(5): 797-816.

44. Linley PA, Joseph S. Positive change following trauma and adversity: a rewiev. J Trauma Stress. 2004; 17(1): 11-21.

45. LeLorain S, Tessier P, Florin A, Bonnaud-Antignac A. Post-traumatic growth in long term breast cancer survivors: relation to coping, social support and cognitive processing. J Health Psychol. 2012; 17(5): 627-639.

46. Znoj H. Bereavement and Post-traumatic Groth. In: Calhoun LG, Tedeschi RG editors. Handbook of Post-traumatic Groth: Research \& Practice. Lawrence Erlbaum Associetes Publishers. Mahwah, NJ; 2006. p.176-196.

47. Teixeira RJ, Pereira MG Factors Contributing to Post-traumatic Growth and Its Buffering Effect in Adult Children of Cancer Patients Undergoing Treatment. J Psychosoc Oncol. 2013; 31(3): 235-265.

48. Nishi D, Matsuok Y, Kim Y. Post-traumatic growth, post-traumatic stress disorder and resilience of motor vehicle accident survivors. Bio Psycho Social Med. 2010; 4(1): 7.

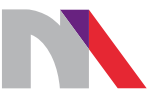

\section{Ministry of Science} and Higher Education

Republic of Poland

Generation of the DOI (Digital Object Identifier) - task financed under the agreement No. 618/P-DUN/2019 by the Minister of Science and Higher Education 